\title{
Collections in the University of
}

\section{North Carolina Library Before 1830}

A STUDY Has recently been made of the earliest holdings of the University of North Carolina Library and a survey taken of the volumes surviving after at least 130 intervening years. Catalogs and other records dated before 1830 were the guides to hundreds of the originally listed copies and to replacements of hundreds more.

On December 5, 1792, the beginning of the University of North Carolina Library was recorded at a meeting of the Board of Trustees: "A book entitled 'the works of the right revered father in God Thomas Wilson D.D. Lord Bishop of Sodor and Man' was presented to the board by the Honle. John Sitgreaves Esqr. agreeably to a resolution of the Congress of the United States passed March 22nd 1785 which was accepted."1 The book had previously been deposited for safekeeping in the library of the New Bern Academy to await the opening of the university, and perhaps the trustees never reclaimed it, for no mention of it occurs in lists of university holdings a few years later, but almost 2,300 of the volumes to come to Chapel Hill during the next thirty-seven years have been identified in the library's present collection. A representative portion of them, in well preserved leather bindings and bearing the original bookplates, have been brought together to form a special

1 Minutes of the Board of Trustees, Dec. 5, 1792, in the University of North Carolina Archives, Southern Historical Collection.

Miss Bahnsen is Assistant Librarian of the North Carolina Collection, University of North Carolina Library. unit in the North Carolina Collection of the University of North Carolina Library, carrying out a suggestion of Miss Mary L. Thornton, librarian of the North Carolina Collection until her retirement on June 30, 1958.

The volumes sought for this "Old Library" representation had belonged in the early days to three separate collections. Administrative officials of the university fostered the first of these, depending on appropriations from the trustees, fees collected from the students, and gifts, which by 1797 had accounted for 133 volumes. Two student organizations, formed in 1796, began at once to build their own libraries. The Dialectic and the Philanthropic Societies, "willing to cultivate lasting Friendship .... and to promote useful Knowledge,"2 counted most of the student body among their members, dominated student life, and for many years supplied the chief extracurricular activities. Their weekly programs consisted of recitations of passages from literature, readings of original compositions, and debates on subjects ranging from the political and sociological to the moral and philosophical. Their books were both the source of their inspiration and the material expression of their intellectual pride. The societies thrived on competition with each other:

And what is told of one library may be told of the other, for they were as much alike as the teeth of the upper and the lower jaw, and as often came into colli-

2 Minutes of the Dialectic Society, 1798-1804, in the University of North Carolina Archives, Southern Historical Collection. 
sion. When one library got a book the other must have the same book, only more handsomely bound, if possible. ${ }^{3}$

The societies' collections, financed by membership dues and augmented by gifts, soon surpassed the university library in quantity and quality as they made its needs less acutely felt. ${ }^{4}$ They belong, their independence notwithstanding, in the search for the origins of today's library because in 1886 they were absorbed by the university library, whose bookplates have ever since carried the phrase "Endowed by the Dialectic and Philanthropic Societies."

As bases of the search for the original volumes, The Catalogue of the Dialectic Society Library and The Catalogue of the Philanthropic Society Library, printed at Chapel Hill in 1829 and 1827, respectively, were chosen because they appeared in close succession at a relatively early date. Since no list of the same period exists for the university library, one appearing in the December 7, 1802 issue of the Raleigh Minerva has been used. Comparisons make it apparent that the society libraries largely paralleled the university collection, and it is unlikely that a catalog of university library books, had one been compiled in the 1820's, would have added many titles to the combined lists mentioned above. The Dialectic Society Catalogue includes 934 titles, or 2,680 volumes; The Philanthropic Society Catalogue, 753 titles, or 2,485 volumes; and the Minerva, 108 titles, or 340 volumes, as well as the collective entries: "174 volumes chiefly in the French language" and "Horace, Virgil, Sallust, Greek Testament, and other School Books." Allowing for titles occurring in more than one of these lists, there

3 William Hooper, Fifty Years Since (Raleigh: Holden and Wilson, 1859), p. 13

1 Each society library held about 3,000 volumes in 1835 , and the university reported 1,900 volumes in 1836.-Kemp P. Battle, History of the University of North Carolina (Raleigh: Printed for the author by Edwards \& Broughton Printing Co., 1907-12), I, pp. $408,410$. is a total of 1,112 separate works, consisting of more than 5,000 volumes.

The information about each book was entered in a card file in the brief form, usually the binder's title, in which it appeared in one or more of the three lists, the number of volumes, and, in the case of gifts, the donor's name. For books from the Dialectic Society, an additional clue lay in that catalog's arrangement of titles in classifications of history, biography, "epistolary," etc. The name of the library or libraries which held copies was indicated on each card. Checking the file against today's card catalog showed many of the titles still to be in the library. For these, full author and title entries were recorded, together with the call number if publication predated 1830. Sometimes more than one modern entry appeared to fit the original specifications as to title, date, and number of volumes, and in such cases all possibilities were noted. No effort was made to find more than one copy or one edition of any title.

Often the brevity and content of the original listing made identification through the card catalog difficult or impossible. The relationship between early and modern entries may be deeply concealed. The title listed as "Amherst's Embassy," for example, was found to be Journal of the Proceedings of the Late Embassy to China...., by Sir Henry Ellis. "Nature and Art" is the old entry for Wonders of Nature and Art, by Thomas Smith. A work of fiction is sometimes listed under its subtitle. Many entries are too vague ever to be identified, such as "Anecdotes, 1 vol." or "French Revolution, 1 vol." "Orsna's Expedition" (The Expedition of Orsua, by Robert Southey) is an example of either misspelling or typographical error, while Adam for Adams and Sullivan for Sulivan are misleading inaccuracies. Fortunately, a little experience in the stacks soon made it possible to spot the leather 
bindings of about the proper age, and the lettering on the spine was an immediate clue to identification; but it is impossible to know how many rebound volumes could not be found in this manner.

More than 900 of the volumes (representing 380 titles), in good condition and in their original bindings, with bookplates or inscriptions indicating the collections with which they had been listed, were withdrawn from the stacks to form the special Old Library collection. Call numbers, date-due slips, and other marks of modern processing were removed. All but the earliest bookplates were taken out-and sometimes five or six had been pasted on top of one another. Loose bindings and pages were made secure and the leather was oiled. After the cataloging had been revised, small gummed labels with new call numbers were placed on the front covers where they would be out of sight when the books were shelved, and bookplates of the North Carolina Collection were pasted inside the back covers. This was considered sufficient marking for volumes to be used only in the building. The books were placed on open shelves in rooms furnished in eighteenth-century style adjoining the reading room of the North Carolina Collection. They are available for use there or in carrels. A separate shelf list records, in addition to full catalog data, the entries used in the pre1830 lists, the name of the libraries which held copies, and all information given on the first bookplates.

The books chosen to be shelved together in this special collection present a picture of the physical nature of the 1830 library resources available in Chapel Hill. The original bindings are invariably leather, mostly in shades of brown, but occasionally black, and often with attractive yellow, green, red, or black labels. A few marbled liningpapers appear. Most of the imprints are of contemporary dates and are predominantly American and English (and there are somewhat more of the American than of the English). A few of the American imprints, usually on theological subjects, carry subscription lists. Novels are, almost without exception, less than nineteen centimeters in height and in two or three volumes. Paper and typography are generally of good quality.

More than 1,400 other volumes (280 titles), named in the early lists and identified by their bookplates as pre- 1830 holdings, remain in the main stacks, the rare book room, and the departmental libraries. Call numbers, complete entries, and bookplate evidence were recorded in the card file used for the search, but the books were not added to the Old Library collection because they are needed in their present location or because they lack their original bindings. In addition to these, about 2,000 volumes (82 titles), named in the early lists and published before 1830 , are in the library today but came from sources other than the pre-1830 collections, or show no evidence of having been in the library at that time. Undoubtedly some are the original copies with bindings and bookplates replaced.

There are 370 titles in the early lists, representing 847 volumes, which cannot now be found in the library in any edition dated before 1830, but an effort was made to supply complete author and title data for these. In most cases this could be done with the aid of the Library of Congress catalog, the British Museum catalog, and The English Catalogue of Books, although the completion of some of the sketchy original entries is questionable. It has been assumed, for example, that "Wonders of the World" is an entry for Book of Curiosities, or, Wonders of the Great World, by John Platts, published in London in 1822; and that "Guion and 
Cowper" is probably Poems, by Jeanne Marie Guyon, translated by William Cowper and including some of his poetry.

A bibliography has been compiled of the books known to have been in the library before 1830.5 It includes the volumes which may be replacements, as well as those known to be the original copies, the latter differentiated by adding the call number for the present location. A supplementary list contains the titles not found in today's library, completing, if possible, the old-style binder's titles. Both lists show the wording of the old entries, the libraries originally holding them, and the number of volumes of each work. Together, these compilations record the literary content of library resources at the university before 1830 and suggest some comparisons and tentative conclusions.

The catalog of the university library printed in the Minerva of 1802 indicated a small but valuable collection. More than half the books were gifts, including "the American edition of the Encyclopaedia, elegantly bound, 18 vols.," large works in history by Hume, Smollett, Gibbon, and Rollin, and a set of maps. The collection is overbalanced in theology, however, by a gift of 174 volumes of religious tracts. The remainder of purchases and gifts reaches into every field of knowledge: strong in philosophy, political science, history, and the Greek and Latin classics, but weak in belleslettres with only Tom Jones, Don Quixote, and "a volume of plays."

On the other hand, the society libraries a quarter of a century later showed their special functions of supplying resources for their programs and for light reading. The classification of literature is their largest, ranging from Shakespeare and Milton to the contemporary

5 Jane C. Bahnsen, "Books in the University of North Carolina Library Since Before 1830" (Typewritten manuscript, University of North Carolina Library, 1958). novelists. Scott, Cooper, Goldsmith, and Fielding are among the most plentifully represented, but-surprising in the man's world of this young college-the "romances" of a number of female writers appear: seven titles by Anna Maria Porter, Paired-Not Matched, by Mrs. Ross, Fashionable Involvements, by Susannah Gunning, and others. The societies had strong collections also in history and biography, and in voyages and travels to all parts of the world. Their works on elocution and collections of oratory must have been useful to the weekly speakers, with such current periodicals as Annual Register, North American Review, and Edinburgh Review to supply timely topics. The lively interest in world affairs is conspicuous in treatises on politics, economics, and law, and in the biography and memoirs of statesmen and military figures. Special attention is devoted to France from the Revolution through the Napoleonic period.

A rough estimate can be made of the distribution by Dewey subject classification of the books investigated by this study. Allowance must be made, of course, for the lack of information about the university collection between 1802 and 1830. About 8 per cent would fall in Religion and in Social Science (300class); 36 per cent are in Literature, 26 per cent in History, and 12 per cent in Biography. There is very little in Fine Arts and Technology, only about 3 per cent in Natural Science, and slightly more in Philosophy.

It is a temptation to speculate as to the books for which no original copies were found. Those of a textbook nature, particularly Greek and Latin, were undoubtedly worn out, as were dictionaries and encyclopedias. Original copies of ephemeral fiction survived in greater number than the works of Scott and Cooper. Collections such as Flowers of Wit and Elegant Extracts may have been 
overworked for society readings. No fire took its toll, although for many years the books were housed on the third floor of a building heated by thirty-two open fireplaces. The largest single disaster occurred in the depredations by occupation troops and vagrants following the Civil War. "The Halls \& Libraries are broken into at all times," wrote Cornelia Phillips Spencer in 1871, "\& I am told the Phi Lib... has its books scattered \& torn all over the building. ${ }^{6}$ Whether those deeds were simple vandalism or purposeful thievery is not indicated. The

- Cornelia P. Spencer, Selected Papers. Edited with an introduction by Louis $R$. Wilson (Chapel Hill: University of North Carolina Press, 1953), pp. 659-60. less dramatic processes of weeding and discarding, as new writings and new editions crowded out the old, have left no record.

These piecemeal analyses and observations are far from adequate to illustrate the beginnings of a great academic library. In terms of the hopes and hardships of the young nation of the early nineteenth century, it was a great library then, drawing largely on the literary wealth of the Old World from Aristotle to Adam Smith, from Xenophon to Voltaire, from Dante to Byron-but listening to the New World's John Adams, Washington Irving, and James Fenimore Cooper.

\section{The New Book Rate and Policy on Interlibrary Loan of Dissertations}

The Committee on Microfilmed Dissertations of the Association of Research Libraries has urged the librarians of the country, as a matter of policy, to purchase microfilm copies of doctoral dissertations accepted by American universities when they are available from University Microfilms in lieu of requesting the interlibrary loan of typewritten copies of these dissertations. Several inquiries have been received recently regarding the effect of the new postal book rate on this recommended policy. It seems to be the assumption that hitherto the cost of shipping a dissertation by express to and from the borrowing library had been sufficiently close to the cost of a positive film copy to warrant relieving the university libraries of this interlibrary loan burden. Now that typed dissertations may be mailed at a low book rate, this argument apparently has lost its validity.

It is the view of the Committee that the existing system should be continued despite the fact that the dissertations may now be mailed at a low postage rate. There still remains the high cost of charging the dissertation to the borrowing library, wrapping it, receiving it when it is returned, and discharging it. At the borrowing end there is the additional cost of record keeping and of wrapping the dissertation for return. It is the view of this Committee that although these costs are concealed in some institutions, they are sufficiently high to justify continuation of the present more convenient system which centralizes the interlibrary loan work on doctoral dissertations included in the ARL program through the purchase of positive microfilm copies from University Microfilms.-Ralph E. Ellsworth, Ralph A. Sawyer, and Frederick H. Wagman. 